\title{
QUALITY OF LIFE IN PATIENTS WITH CHRONIC VENOUS DISEASES AND METHODS OF ITS IMPROVEMENT (REVIEW)
}

\author{
Pytetska N. I.
}

\begin{abstract}
Summary. Assessment of the quality of life is one of the leading directions in modern medicine and continues to develop intensively, remaining an integral part of comprehensive analysis of new methods of diagnosis, treatment and prevention. This article provides information about the history of the concept "quality of life" and the ambiguity of terminology. Particular attention is paid to the necessity of studying this indicator in patients with chronic veins diseases, the relevance of this direction in the early stages of the disease, as well as medicines able to solve the main tasks of drug therapy, to restore work capacity and, as a result improve the patient's life quality.
\end{abstract}

Key words: quality of life, chronic venous diseases, diosmin.

The learning of quality of life, that based on health assessment is one of the leading directions in modern medicine. It continues to develop intensively and remains as an integral part of the comprehensive analysis of new methods of diagnosis, treatment and prevention. This concept came to medicine from sociology and meant the totality of work and rest, quality of clothes, habitation, nutrition and environmental conditions.

The history of life quality research was started in 1949 after publication of the article "Clinical evaluation of chemotherapy in cancer" written by the professor D.A. Karnovsky from the Columbia University [1]. The necessity of studying psychological and social consequences of the disease together was identified as a result of prolonged observation of cancer patients. The term "quality of life" was used first by J.R. Elkington in 1966 in the "Medicine and quality of life" [2]. This term was recognized in medicine, using as a heading in "Cumulated Index Medicus" in 1977 [3]. The conception and development of the basic techniques for the studying of quality of life in various diseases was determined in the following decades [4-7]. MAPI Research Institute, which was not only the center for the

\footnotetext{
Corresponding Author:

Natalia Pytetska, MD, PhD, Professor

of the Department of Fundamentals

of Internal Medicine No. 1,

Fundamentals of Bioetics and Biosafety.

Kharkiv National Medical University, Ukraine.

E-mail:natalia.pytetska@gmail.com
}

study of quality of life but also for the coordinator of all researches about life quality in the world, has been functioning in France since 1995.

Up to now there are different definitions of quality of life. A.Novik, T.Ionova (1999) defined it as an inseparable relationship of the basic human states: emotional, physical, psychological and social [3], N. Senkevich, A.Belyavsky (2000) as a comfort level of the individual within himself and the livability in the society where he lives [8]. The WHO defined the quality of life as a state of complete physical, mental and social wellbeing [9]. Nevertheless, it is generally accepted that this concept is multidimensional and reflects the impact of disease and treatment on the patient's state of health.

The study of quality of life is actively conducted in all fields of medicine [4-8], including phlebological practice, which is associated with high prevalence of chronic venous diseases. The studies on quality of life evaluated various treatment options of chronic venous diseases [10], adherence to systemic therapy of post-thrombotic disease [11], comparing conservative and surgical methods of treatment [12] allowing to evaluate the patient's perception of the outcome of any treatment.

To date, the prevalence of chronic venous insufficiency (CVI) according to various authors is $1-40 \%$ among women and $2-17 \%$ among men, the prevalence of varicose disease of the lower extremities is $1-73 \%$ among women and $2-56 \%$ among men [13]. Almost every $2^{\text {nd }}$ inhabitant of the planet suffers from varicose veins already, 2 sick men account for 3-4 sick women, $62.3 \%$ 
of whom are women of reproductive age [14]. The number of schoolchildren who are found to have early signs of venous reflux is growing [15]. The highest prevalence of chronic venous diseases was observed at the age of 25-50 years - in the most socially active part of the population. According to the Edinburgh study (1999), chronic venous diseases were more common in men than in women, and their prevalence increased with age [16]. People over the age of 80 have a tendency to decrease the incidence of CVI, while the amount of complications increases [17].

High incidence allows to call CVI "a disease of civilization". The basis for this assessment of the disease was the fact that most people suffer from this disease, live in cities and in economically developed countries $[18,19]$. Complicated forms of CVI are accompanied not only by cosmetic inconveniences, but also by the development of persistent and prolonged disability. About $1 \%$ of the population has acute or chronic ulcers, more than $50 \%$ of which require long-term therapy. The incidence of deep vein thrombosis is 100 per 100000 population [20]. The development of chronic varicose diseases was shown to reduce quality of life [21,22], while the improvement of the patient's condition after the treatment increases it [23-25].

Thus, increase in prevalence of CVI and its complications results in a disruption of the ability to engage in social and professional activities, a decrease in the quality of life and emergence of financial constraints, which is accompanied by an increase in economic costs in healthcare. For example, about 1 billion dollars a year are spent on the treatment of CVI and its complications in the United States, up to $2 \%$ of the total health budget in all western countries, that raises the importance of this problem according to understanding of clinical manifestations, improving diagnostic methods and therapeutic possibilities [26].

There are many factors to formation of pathological ectasia, among which predisposing factors (genetic, mechanical) and realizing factors (lifestyle, reception of contraceptives, tight shoes, etc.) are distinguished. Their interaction helps to reduce the tone of the venous wall and leads to venous stasis which initiates a cascade of pathological changes on the molecular, cellular and tissue levels. As a result, it triggers conditions for increased thrombus formation.

Over the past 30 years a number of classifications of varicose veins, post-thrombotic syndrome and actual CVI of the lower extremities have been proposed. The best known classification of varicose disease was suggested by F. Martorell (1972), H.J. Leu (1979), CVI Widmer (1978), J. Porter (1988), V.S. Savel'eva (1972). The international classification of CEAP (1994), along with clinical manifestations of CVI, reflects the quality of life of the patient [27].

The initial degree of CVI is characterized by functional symptoms without special cosmetic effects. But such complaints as paresthesia, skin itching, night cramps can reduce the patient's QL. Progression of CVI manifested by persistent severe pain in the lower extremities and edema, increased after insignificant physical exertion, development of hyper- or hypopigmentation, trophic skin disorders and their complications sharply reduce patient's quality of life, lead to a decrease or loss of ability to work and permanent disability. Therefore, early symptoms should be regarded as a signal that the patient should see a doctor.

Subjective and objective methods of investigation are important to confirm a disorder of the venous system of the lower limbs and determine the kind of treatment. Thorough history taking is vital: characteristics of work and sport activity, characteristics of everyday clothes, past medical history, family history, etc. On examination it is necessary to inspect both lower extremities, inguinal areas, anterior and lateral walls of the abdomen, paying attention to the presence of dilated intradermal and subcutaneous veins, signs of varicose veins of large and small saphenous veins and presence of edema and trophic disorders on the skin of the legs. Dilation of veins on the legs can vary from small vascular "asterisks" and intradermal (reticular) nodules to large sinuous trunks, nodes, protruding plexuses that clearly appear in the vertical position of the patient.

Palpation allows to reveal the signs of thrombophlebitis and to determine the boundary zone of indurative cellulitis. Extended veins are elastic consistency, easily compressed with increased skin temperature above them. In recumbent position, the tension of the veins and the size of the varicose veins is decreased.

In all cases it is necessary to determine the pulsation of the arteries on feet. Instrumental diagnostic methods are used in cases when diagnosis and the nature of treatment are not clear, the scope of possible surgical manipulations is unclear.

Treatment of CVI should be complex and combine medical therapy, compression, sclerotherapy and surgical treatment. In recent 
decades, the role of pharmacotherapy has significantly increased, the main goals of which are elimination / reduction of CVI, prevention of recurrence of the disease, postoperative rehabilitation, retention of work capacity, improvement of patient's quality of life, and prevention of CVI in risk groups. Oral venotropic drugs of plant or synthetic origin are able to solve the main tasks of drug therapy.

There are 4 groups of phlebotonics. So far drugs have been based on diosmin, which is considered to be the reference chemical compound for the production of various dosage forms [28]. This is natural isoflavonoid, obtained from plants of the Rutaceae family and it can be obtained by chemical synthesis [29]. Clinical efficacy and safety of diosmin have been widely studied. It has been shown to accumulate in venous vessels [30], to reduce norepinephrine metabolism in comparison with patients who did not take this drug [31], to improve microcirculation [32]. A clinical study with 16728 patients has convincingly demonstrated the ability of diosmin $(600 \mathrm{mg})$ to effectively reduce the perimeter of the ankle independently from the age, gender and degree of CVI, good tolerance and low incidence of side effects [33], so it remains the drug of choice at all stages of the disease, including complicated forms [34]. Semisynthetic diosmin $600 \mathrm{mg}$ was taken once a day and $300 \mathrm{mg}$ was taken twice a day by 255 patients. It was compared in a double-blind, placebo-controlled therapeutic study. The obtained results were comparable, but clinical effect was more rapid with the $600 \mathrm{mg}$ diosmin taken once a day [35]. In a prospective study with 80 patients, monotherapy with high diosmin dose showed reliable reduction of the severity of clinical symptoms of CVI, and changing the stage of the disease (according to the CEAP classification), and improvement of the quality of patient's life [36].

In addition, diosmin in the dose of $600 \mathrm{mg}$ is successfully used in obstetrics and gynecology, it is not contraindicated to pregnant women $[37,38]$, has a positive effect onn glucose metabolism [39, 40], hepatoprotective effects [40] and is used in the treatment of cardiovascular diseases [41].

Thus, diosmin-containing venoprotectors are a bioavailable and biosafe group of drugs that are effective at all stages of chronic veins diseases, including complicated forms, and in patients with accompanying therapeutic pathology. Long-term administration of high doses of diosmin promotes regression of the disease, manifested by a decrease in the severity of clinical manifestations, improvement of venous and lymphatic outflow, correction of hemorheological disorders with minimal side effects. This leads to the restoration of work capacity and, as a result, to improving of the quality of the patient's life.

\section{Conflict of interests}

There is no conflict of interests.

\section{References}

1. Karnofsky, D.A., Burchenal, J.H. (1949) The clinical evaluation of chemotherapeutic agents in Cancer. In Evaluation of chemotherapeutic agents, C.M. MacLeod (ed). New York: Columbia University Press, 191-205.

2. Elkington, J.R. (1966) Medicine and the quality of life. Annals of Internal Medicine, 64 (3), 711-714.

3. Novik, A.A., Ionova, T.I. (2007) Rukovodstvo po issledovaniyu kachestva zhizni v meditsinye [Guide to the study of quality of life in medicine]. 2-ye izdaniye / Pod red. akademika RAMN Yu.L. Shevchenko, M.: ZAO "OLMA Media Grup", 320 p.

4. Melikyan, E.G., Milchakova, L.E., Geht, A.B. Kontseptsiya kachestva zhizni v epileptologii [The concept of quality of life in epileptology]. Zhurnal Nevrologii i Psihiatrii imeni C.C. Korsakova. Epilepsiya, vypusk 3, pp, 28-35.

5. Vnukov P.V. (2014) K voprosu ob otsenke reproduktivnoy sfery I rfchestva zhizni u muzhchin v posleoperatsionnom periode posle pahovoy gernioplastiki [On the issue of assessing the reproductive health and quality of life in men in the postoperative period after inguinal hernioplasty]. Nauka u molodyh-Eruditio Juvenium, no3, pp. 64-71.

6. Kubazhi, H., Magraui, U., Rakita, D.R. Solovyeva, A.V. (2012) Kachestvo zhizni bolnyh hronicheskoy obstruktivnoy boleznyu legkih v sochetanii s ishemicheskoy boleznyu serdtsa [Quality of life of patients with chronic obstructive pulmonary disease in combination with ischemic heart disease]. Rossiyskiy mediko-biologicheskiy vestnik imeni akademika I.P. Pavlova, no 3, pp. 87-93.

7. Anthony, S.J., Selkirk, E., Sung, L., Klasen, R.J., Dix, D., Scheinemann, K., Klassen, A.F. (2014) Considering quality of life for children with cancer: a systematic review of patient-reported outcome measures and the development of a conceptual model. Quality of Life Research, 3, 771-789. 
8. Senkevich, N.Yu., Belyavskiy, A.S. (2000) Kachestvo zhizni predmet issledovaniya v pulmonologii [Quality of life is the subject of scientific research in pulmonology]. Terapevticheskiy arhiv, no 3, pp. 35-37.

9. The WHOQOL Group. World Health Organization Quality of Life Assessment (1996) What quality of life? World Health Forum, 17(4), 354-356.

10. Tsukanov, Yu.T, Tsukanov, A.Yu. (2003) Kachestvo zhizni bolnyh pri hirurgicheskom lechenii varikoznogo rasshireniya ven nizhnih konechnostey [Quality of life of patients with surgical treatment of varicose veins of lower extremities]. Hirurgiya, no 11, pp. 11-16.

11. Ivanov, E.V. (2015) Zavisimost kachestva zhizni patsientov s HBN klassa C4OT komplaentnosti pri ambulatornom lechenii [Dependence of quality of life of patients with CVI of C4OT class of compliance with outpatient treatment]. Materialy XXX Mezhdunarodnoy konferentsii Possiyskogo obshchestva angiologov I sosudistyh hirurgov, Sochi, 25-27615, pp. 212-214.

12. Zolotuhin, I.A.,Yumin, S.M., Leontev, S.G., Andriyashkin A.V., Kirienko A.I. (2011) Otdalennye rezultaty lecheniya patsientov, perenesshih tromboz glubokih ven nizhnih konechnostey [Long-term results of treatment of patients who underwent thrombosis of deep veins of lower extremities]. Flebologiya, tom 5, no1, pp. 27-33.

13. Beebe-Dimmer, J.L., Pfeife,r J.R., Engle, J.S., Schottenfeld D. (20050 The epidemiology of chronic venous insufficiency and varicose veins. // Annals of Epidemiology, 15(3), 175-184.

14. Murashko A.V. (2005) Zabolevanie ven i beremennost [Vein disease and pregnancy]. Ginekologiya, tom 7, no 5-6, pp. 316-318.

15. Serov V.N. Zharov E.V. (2014) Hronocheskaya venoznaya nedostatochnost [Chronic venous insufficiency]. Semeynaya meditsina, no 6, pp. 14-20.

16. Evans, C.J., Fowkes, F.G., Ruckley, C.V., Lee, A.J. (1999) Prevalence of varicose veins and chronic venous incificiency in men and women in the general population: Edinburg Vein Study // Journal of Epidemiology and Community Health, 53(3), 149-153.

17. Cesarone, M.R., Belcaro, G., Nicolaides, A.N., Geroulacos, G., Griffin, M., Incandela, N....Veller, M. (2002) 'Real' epidemiology of varicose veins and chronic venous diseases: the San Valentino Vascular Screening Project. Angiology, 53(2), 119-130.

18. Robertson, L., Evans, C., Fowkes, F.G. (2008) Epidemiology of chronic venous disease. Phlebology, 23(3), 103-111.

19. Kosinets, A.N., Petuhov, V.I. (2002) Varikoznoe rasshirenie ven nizhnih konechnostey [Varicose veins of lower extremities]. Vitebsk, VGMU, $200 \mathrm{p}$.

20. Birdwell, B. (1999) Recent clinical trials in the diagnosis ofdeep-veinthrombosis. // Current Opinion in Hematology, 6 (5), 275-279.

21. Klyscz, T., Junger, M., Schanz S., Janz, M., Rassner, G., Kohnen, R. (1998) Quality of life in chronic venous insufficiency (CVI). Results of a study with the newly developed Tubingen Questionnaire for measuring quality of life of patients with chronic venous insufficiency. Hautarzt, 49, 372-381.

22. Morgan, P.A., Franks, P.J., Moffatt, C.J., Doherty, D.C., Connor, T.O., McCullagh, L., Hourican C. (2004) Illness behavior and social support in patients with chronic venous ulcers. Ostomy Wound Manage, 50 (1), 25-32.

23. Benigni, J.P., Sadoun, S., Allaert, F.A., Vin, F. (2003) Efficacy of Class 1 elastic compression stockings in the early stages of chronic venous disease. A comparative study. International Angiology, $22,383-392$.

24. Jantet, G. (2002) Chronic venous insufficiency: worldwide results of the RELIEF study. Reflux assessment and quality of life improvement with micronized Flavonoids. Angiology, 53, 245-256.

25. Lozano, F.S., Launois, R. (2002) Quality of life (Spain and France): validation of the chronic venous insufficiency questionnaire (CIVIQ). Methods and Finding in Experimental and Clinical Pharmacology, 24, 425-429.

26. Eberhardt, R.T., Raffetto, J.D. (2005) Chronic venous insufficiency. Circulation, 111, 23982409.

27. Eklof, B., Rutherford, R.B., Bergan, J.J., Carpentier, P.H., Gloviczki, P., Kistner, R.L .... Wakefield T.W. (2004) Revision of the CEAP classification for chronic venous disorders: consensus statement. Journal of Vascular Surgery, 40, 1248-1252.

28. Casley-Smith, J.R., Casley-Smith, J. (1985) The effect of diosmin (a benzo-pyrone) upon some highprotein oedemas: lung contusion, burn and lymphoedema of the rat legs. Agents and Actions, 17, 14-20. 
29. Tarahovskiy, Yu.S., Kim, Yu.A., Abdrasilov, B.S., Muzafarov, E.N. (2013) Flavonoidy: biohimiya, biophizika, meditsina: Pushchino, Synchrobook, $310 \mathrm{c}$.

30. Duperray, B., VierinJ., Pacheco, H. (1984) Pharmacokinetics and biochemical pharmacology of diosmin in animals. In Medical Therapy, J.A. Dormandy (ed.): Panminerva Medica, 182-185.

31. Araujo, D., Viana, F., Osswald, W. (1991) Diosmin Therapy Alters the in vitro metabolism of noradrenaline by the varicose human saphenous vein. Pharmacology Research, 24 (3), 253-256.

32. Zasorin, A.A., Makarova, N.P., Naritsina V.V. (2011) Vliyanie diosmina na microtsirkulyatsiyu pri vyalotekushchih ranah [Influence of diosmine on microcirculation with sluggish wounds]. Flebologiya, 1, 24-26.

33. Pokrovskiy, A.V., Sapelkin, C.V. (2005) Proizvodnye polusinteticheskogo diosmina v lechenii bolnyh s hronicheskoy nedostatochnostyu - rezultaty prospektivnogo issledovaniya s primeneniem preparata Flebodia 600 [Derivatives of semi-synthetic diosmine in treatment of patients with chronic venous insufficiency - results of a prospective study with using of Flebodia 600], Angiologiya i Sosudistaya hirurhiya, 11 (4), 73-84.

34. Batchvarov, I.V., Batselova, M.G. Damyanov I.I. (2010) One-year diosmin therapy (600 mg) in patients with chronic venous insufficiency - Results and analysis. Journal of Biomedical and Clinical Research, 3, 51-54.

35. Carpentier, P.H., Maricq, H.R., Biro, C., Poncot-Makinen, C.O., Franco, A. (2004) Prevalence, risk factors and clinical patterns of chronic venous disorders of lower limbs: A population-based study in France. Journal of Vascular Surgery., 40 (4), 650-659.

36. Macsimovic, Z.V., Macsimovic, M., Jadranin, D., Kuzmanovic, I., Andronovic O. (2008) Medicamentous treatment of chronic venous insufficiency using semisynthetic diosmin - a prospective study. Acta Chirurgica Iugoslavica, 55 (4), 53-59.

37. Shibelgut N.M., Baskakova T.B., Zaharov I.S., Mozes V.G. (2010) Effektivnost diosmina $600 \mathrm{mg}$ pri provedenii profilactiki proingredientnogo techeniya varikoznoy bolezny malogo taza $\mathrm{u}$ beremennyh: rezultaty prostoho slepogo randomizirivannogo platsebo-kontrolirovannogo issledovaniya [Efficacy of the $600 \mathrm{mg}$ diosamine in the prevention of the progressive course of varicose veins of the pelvic floor in pregnant women: the results of a simple, blind, randomized, placebo-controlled study]. Rossiyskiy vestnik akusherstva i ginekologii, 3, 27-32.

38. Lahno, I.V., Barannik, E.A., Tkachev A.E. (2011) Novaya metodologiya izucheniya effektov diosmina $\mathrm{v}$ perinatalnoy meditsine [A new methodology for studying the effects of diosmin in perinatal medicine]. Zdorove zhenshchiny, 10, 110-113.

39. Srinivasan, S., Pari, L. (2012) Ameliorative effect of diosmin, a citrus flavonoid against streptozotocin-nicotinamide generated oxidative stress induced diabetic rats. Chemico-Biologocal Interactions, 195 (1), 43-51.

40. Pari, L., Srinivasan, S. (2010) Antihyperglycemic effect of diosmin on hepatic key enzymes of carbohydrate metabolism in streptozotocin-nicotinamideinduced diabetic rats. Biomedical Pharmacotherapy, 64, 477-481.

41. Silambarasan, T., Raja, B. (2012) Diosmin a bioflavonoid reverses alterations in blood pressure, nitric oxide, lipid peroxides and antioxidant status in DOCA-salt induced hypertensive rats. European Journal of Pharmacology, 679, 81-89.

Received: 03-Jan. - 2018

Accepted: 11-Apr. - 2018 